\title{
MANCIPATIO BY AN AGENT AND THE SATISDATIO AND REPROMISSIO SECUNDUM MANCIPIUM AS SURETIES FOR EVICTION
}

\author{
Javier E Rodríguez Diez*
}

\section{ABSTRACT}

The satisdatio secundum mancipium and the repromissio secundum mancipium were the first stipulations for eviction granted by the seller in Roman private law. The obscurity of the sources on the subject has given place to various theories concerning the exact role of these institutions. This article attempts to analyse the available evidence by revisiting the traditional idea of the impossibility of an agent to mancipate, concluding that the role of the satisdatio and repromissio secundum mancipium was to grant the buyer a surety against eviction when an agent mancipated on behalf of the owner. This role would better explain the features of these institutions compared to other mechanisms protecting the buyer, such as the stipulatio duplae and the exceptio rei venditae et traditae. The sources suggest that a need for such surety was triggered by the absence of responsibility for auctoritas following from a mancipatio by an agent. This surety has moreover left traces in Roman legal practice, which confirm the role of these stipulations and their practical importance.

Keywords: satisdatio secundum mancipium; repromissio secundum mancipium; eviction; auctoritas; stipulatio duplae; exceptio rei venditae et traditae

* Assistant professor of Roman law, Pontificia Universidad Católica, Chile. This article is part of Project Fondecyt n 1180022, where the author participates as co-researcher. 


\section{Introduction}

The satisdatio and repromissio secundum mancipium are troubling concepts for Roman law scholars. They are often indicated as the first stipulations against eviction, which implies that they form a bridge between the actio auctoritatis and the stipulations for eviction. However, the sources offer only a handful of concise texts on the subject, leaving countless questions unanswered concerning not only the exact role of these institutions, but the very origins of the stipulations for eviction.

The scarcity of the sources has led scholars to suggest various theories on the exact role of the satisdatio and repromissio secundum mancipium. The most successful theory in the last decades has been proposed by Hans Ankum, according to whom these institutions would have served the purpose of making the seller liable for eviction in the same way as if he had mancipated when he delivered a res mancipi by traditio. Such sureties would have been granted when it was not possible to mancipate, as would allegedly be the case when an agent mancipated. This theory is more satisfactory than previous ones, since it offers a comprehensive approach to the different sources on the subject. It does, however, face serious objections. For instance, the scope granted by Ankum to the satisdatio and repromissio secundum mancipium seems to overlap with that of the stipulatio duplae, which was granted in the context of the sale of res mancipi. The same can be said regarding the exceptio rei venditae et traditae, which could be granted in favour of a buyer who acquired a res mancipi by traditio.

The overlap between the fields of application of these institutions suggests that the role of the satisdatio and repromissio secundum mancipium must be found elsewhere. This article offers an alternative explanation by revisiting the traditional assumption that the mancipatio could not be concluded by an agent. By challenging this idea, the article proposes a revision of the sources and the existing theories on the satisdatio and repromissio secundum mancipium, explaining them as sureties granted by the mancipio dans who act on behalf of the owner, replacing the absence of liability for auctoritas. As it will be shown below, this role can better explain the rather specific scope of the satisdatio and repromissio secundum mancipium, unlike the broader role fulfilled by the stipulatio duplae and the exceptio rei venditae et traditae. Moreover, the scope of these sureties allows a better understanding of their role in the evolution of the stipulations for eviction.

\section{The evidence in the sources}

The sources concerning the satisdatio and repromissio secundum mancipium are so scarce that there is only one text which mentions both institutions side by side, namely the formula Baetica. This text dates from the first or second century AD and contains the acquisition fiduciae causa of a piece of land as well as a slave by the creditor Lucius Titius, which was mancipated to his slave Dama - who thereby 
acquires ownership on behalf of his master - by his debtor Baianus. When describing the way in which Titius may alienate the land he acquired, the text reads as follows: "mancipio pluris HS n(ummo) I invitus ne daret, neve satis secundum mancipium daret, neve ut in ea verba, quae in verba satis s(ecundum) $\mathrm{m}$ (ancipium) dari solet repromitteret neve simplam neve [duplam] ". ${ }^{1}$ According to this text, the creditor who acquires fiduciae causa may transfer ownership over the things received without being compelled to give any surety against eviction. This feature has been explained because the creditor does not know the origin of the goods acquired, and therefore he would be assuming a considerable risk in case he obliged himself for the event of the eviction. ${ }^{2}$

When describing the creditor's exemption from assuming responsibility for eviction, we are told that he may mancipate for one sesterce - thereby avoiding to become liable for auctoritas ${ }^{3}$ - and that he is moreover not obliged to grant a satisdatio secundum mancipium ("neve satis secundum mancipium daret") nor a repromissio containing the same wording of the satisdatio secundum mancipium ("neve ut in ea verba, quae in verba satis s(ecundum) m(ancipium) dari solet, repromitteret"). Also, the stipulatio simplae or duplae ("neve simplam neve [duplam]") are excluded. ${ }^{4}$

While the text is rather brief concerning the institutions under analysis, it does offer valuable information. First, the satisdatio and repromissio secundum mancipium are set side by side with the stipulatio duplae and simplae, which strongly suggests that they constitute sureties against eviction. ${ }^{5}$ It is moreover interesting to note that the repromissio secundum mancipium is described by reference to the satisdatio secundum mancipium, which indicates that the latter was better known and was probably more common. ${ }^{6}$ This also implies that the content of both acts was the same, having an identical wording. ${ }^{7}$ The only difference between them is that one act consists on a repromissio, which is merely a stipulation, while the satisdatio consists in a stipulation which is further guaranteed by a personal security (sponsio, fideipromissio or fideiussio). ${ }^{8}$ Accordingly, the buyer would be more secured through the satisdatio than through the repromissio.

1 FIRA 1968: vol 3297 (§ 92). Translated by Ankum 1978: 11-12: “[t]hat he will not have to mancipate against his will for more than one sestertius and that he had not to give a satisdatio secundum mancipium, neither a promise in the form of a stipulatio with these words, which are generally inserted in a satisdatio secundum mancipium, nor to make a stipulatio simplae or duplae (for the case of eviction)."

2 Ankum 1981: 756-757.

3 Ankum 1979: 31-33; Ankum 1981: 758; Brägger 2012: 93-95; Guida 2013: 63.

4 Bechmann 1876: 370 n 3; Girard 1923: 58-59; Arangio-Ruiz 1954: vol 2 330; Ankum 1981: 759.

5 Arangio-Ruiz 1954: vol 2 330; Ankum 1981: 759-760; Brägger 2012: 118.

6 Ankum 1981: 759.

7 Lenel 1927: 547.

$8 \quad$ Girard 1923: 60; Sargenti 1962: 153-154; Ankum 1981: 747-748. 
To conclude the analysis of the formula Baetica, one should bear in mind that this text describes the acquisition of ownership fiduciae causa through an intermediary - the slave Dama - which could eventually imply that the subsequent sale of the res mancipi could be performed through the same intermediary. This should be borne in mind since, as it is shown below, other texts regarding the satisdatio and repromissio secundum mancipium concern situations where an agent transfers ownership, which could explain the role of these institutions. If this is indeed the case, the formula Baetica would therefore list all the possible grounds of eviction, whether the thing was conveyed by mancipatio or traditio, by the owner or by an agent.

Another classical text, referring solely to the satisdatio secundum mancipium, is found in the letters of Cicero to Atticus, where the former writes: "De Annio Saturnino curasti probe. De satis dando vero, te rogo, quoad eris Romae, tu ut satisdes. Et sunt aliquot satisdationes secundum mancipium, veluti Memmianorum praediorum vel Attilianorum." ${ }^{\prime \prime}$ In this letter, Cicero thanks his friend for taking care of some affairs in Rome and reminds him to perform the satisdatio secundum mancipium regarding some pieces of land while he is in Rome. The context of the letter would suggest that these satisdationes have something to do with the administration of Cicero's property by Atticus, that has led some scholars to consider that these pieces of land would have been sold recently by Atticus on behalf of Cicero, thereby acting as his procurator, and that Atticus himself should now grant the satisdatio. ${ }^{10}$

A third text, referring to the repromissio secundum mancipium, ${ }^{11}$ may be identified in the Persa of Plautus. In this play a letter is brought to the pimp Dordalus by the slave Tosilus, who claims to have received it from a Persian friend offering him a beautiful slave woman for sale. The letter was allegedly given to Tosilus by a young Persian, whose legal position - procurator, mandatarius, messenger, etc - is not revealed. ${ }^{12}$ The slave woman would have been stolen from Arabia, which is why the seller is unwilling to assume any form of surety in case of eviction; all the risk of the operation would be borne by the buyer. ${ }^{13}$ Regarding this point, the letter reads as follows: "ac suo periculo is emat qui eam mercabitur: mancipio neque promittet neque quisquam dabit."14

9 Cicero Ad Atticum 51 2: "You took good care of the affair with Annius Saturninus. I ask you to give the surety yourself while you are at Rome. There are some satisdationes secundum mancipium [that need to be given], like those of the states of Memmius or Attilius."

10 Ankum 1981: 763-764. Sargenti 1962: 154 appears, however, less willing to fill in the gaps.

11 Girard 1923: 60; Ankum 1981: 760-762; Guida 2013: 65.

12 For a detailed description of the facts of the play, see Ankum 1979: 9-11 and Cristaldi 2011: $517-$ 523. Ankum 1981: 760 assumes that the young Persian acts as a mandatarius or procurator.

13 Ankum 1981: 761; Cristaldi 2011: 519-520; Guida 2013: 65.

14 Plautus Persa 523-524. "He who buys her does it at his own risk: / no one will perform the promissio secundum mancipium or deliver her through mancipatio." This somewhat free translation accepts the opinion that the word promittet would refer to the repromissio secundum mancipium. On the various interpretations of this fragment, see Cristaldi 2011: 518 n 116. 
Once again, the text is not very descriptive, but it does offer some valuable information, specifically that the sale of a slave concluded by an intermediary - in this case, the young Persian who would bring the letter-would normally involve a mancipatio and a promissio related to it, but in this case, no one would perform these acts. ${ }^{15}$

There is further evidence concerning these institutions in post-classical sources which are even more laconic. For example, the Fragmenta Vaticana incidentally mention a certain "stipulatio auctoritatis" when indicating that the eviction through an unjust decision would not make the seller liable. ${ }^{16}$ Since the responsibility for auctoritas sprung instantly when the seller mancipated, scholars consider that this curious expression could only refer to the repromissio secundum mancipium. ${ }^{17}$ More explicit is the reference within the Iuridicarum vocum explanatio (also known as notae Lindenbrogianae), a compilation of legal abbreviations of unknown date, where the letters "s.s.m" are rendered as "satis secundum mancipium". ${ }^{18}$ While these texts tell us virtually nothing on these institutions, they indicate that these sureties remained in force through the classical and even the post-classical period.

At this point, it should be noted that there are no references to the satisdatio or repromissio secundum mancipium in Justinian's Corpus Iuris, which suggests that the compilers deliberately eliminated every reference to these institutions, mechanically replacing them by references to the stipulatio duplae. Nonetheless, scholars have been able to identify several texts which would originally have referred to the repromissio or satisdatio secundum mancipium. ${ }^{19}$ Within the Edict, between the titles regarding the cautio rem ratam haberi and the cautio ex operis novi nuntiatione, there are texts dealing with the liability for double the price in case a res mancipi was evicted. While some authors claim that this title referred to the stipulatio duplae,$^{20}$ scholars such as Lenel and Ankum have argued that the Edict of

15 The fact that the promissio would be coupled with the mancipatio may be seen in the fact that, later in the play, reference is made only to the mancipatio. Plautus Persa 532: "Nisi mancipio accipio, quid eo mihi apud mercimonio?" (If I do not acquire by mancipatio, what need do I have of this merchandise?); Persa 589: "Prius dico: hanc mancipio nemo tibi dabit. Iam scis? - Scio" (I tell you first: no one will mancipate her to you. Do you already know this? - I know). Contrary to this view, see Brägger 2012: 48.

16 FV 10: "Iniquam sententiam evictae rei periculum venditoris non spectare placuit neque stipulationem auctoritatis committere."

17 Lenel 1927: 548; Ankum 1981: 762-763; Brägger 2012: 192.

18 Keil \& Mommsen 1864: 300. See, on this text, Ankum 1981: 764.

19 Ankum 1981: 765-767, 777-788; Ankum 2013: 20-22, 24-27 regards as originally referred to the satisdatio or repromissio secundum mancipium PS 217 1, PS 5, 10, D 212 76, D 212 53, D 1378 1, D 1911317 and D 19111 8-9. Later, (Ankum 2013: 15, 22-24) he adds to this list D 212221 (following Ernst 1995: 23 n 89), D 212 69 3, D 212412 and D 212 43. Moreover, in this latter work (Ankum 2013: 17-18) he discards that PS 2171 must have been referred to the repromissio or satisdatio secundum mancipium. To this list one may add D 21251 , following Lenel 1889: vol 1 col 464 n 7, as well as D 212 20, following Lenel 1889: vol 2 col 113 n 2.

20 Girard 1923: 131-134, followed by Meylan 1948: 6-9, 26-27. 
the praetor at this point dealt with the actio auctoritatis and, immediately thereafter, with the satisdatio secundum mancipium. ${ }^{21}$ Such a claim agrees with the wording of several of these texts, such as D 212 40, where the satisdatio secundum mancipium is barely hidden behind the words "satis a me de evictione accepit". ${ }^{22}$ This conclusion has also been ratified by the analysis of the various texts, which shows that in several cases the outcome is different to that of the stipulatio duplae. ${ }^{23}$ Moreover, scholars have pointed out that the stipulatio duplae should have been dealt with by the aedile in his Edict, and not by the praetor. ${ }^{24}$ It should be noted that jurists might as well have discussed problems related to the repromissio secundum mancipium, and not only the satisdatio. The state of the sources often makes it impossible to determine which of these institutions was under analysis in specific fragments. ${ }^{25}$

The palingenetic analysis of Lenel shows that the liability for auctoritas and the satisdatio secundum mancipium were dealt with one after the other within the Edict, as can be seen in the distribution of classical works which follow the titles of the Edict. ${ }^{26}$ Auctoritas was dealt with by Julian in book 57 of his Digesta; by Venuleius in book 16 of his work on stipulations; by Paul in book 76 of his ad Edictum; and by Ulpian in book 80 ad Edictum, the satisdatio secundum mancipium was analysed in Julian's book 58 of his Digesta, Venuleius' book 17 on his work on stipulations, Paul's book 77 of his ad Edictum and Ulpian's book 81 ad Edictum. The distribution of titles within this part of the Edict has been explained because of the presence of the satisdatio secundum mancipium, which would have been first grouped along with other cautiones within the Edict, dragging the actio auctoritatis along with it. ${ }^{27}$ The surviving texts on the subject are scarce, which has been regarded by some scholars as proof of the limited significance of these sureties already in classical times..$^{28}$ Even if that was the case - which is by no means evident - the fact that these jurists dealt with the repromissio and satisdatio shows that these institutions had not disappeared by their time.

This brief survey of the sources offers some relevant clues concerning the satisdatio and repromissio secundum mancipium. We know, for instance, that both sureties had an identical content, which was securing the buyer against eviction. ${ }^{29}$ We also know that these institutions were around for quite some time - despite the fact of being only seldom mentioned in surviving sources - from the archaic to the

21 Lenel 1889: vol 1 col 464 n 8; Lenel 1927: 542-543, 546-549; Arangio Ruiz 1954: 332; Ankum 1979: 33-36; Ankum 1981: 768-788.

22 Lenel 1889: vol 1 col 464; Arangio Ruiz 1954: 332; Ankum 1981: 771, 775; Brägger 2012: 210.

23 Ankum 1979: 36-43.

24 D $4515 \mathrm{pr}$. See, further, on this point Ankum 1981: 769-770.

25 Ankum 1981: 774; Ankum 2013: 18-19.

26 Lenel 1927: 547.

27 Lenel 1927: 543; Ankum 1981: 771-772; Brägger 2012: 223.

28 Arangio-Ruiz 1954: 332. This claim is also made by Guida 2013: 67.

29 Girard 1923: 57-58. 
postclassical period,$^{30}$ but that all references to them were removed by Justinian. The satisdatio seems, moreover, to have been more common or better known than the repromissio. Finally, the sources often present these institutions in a context where an agent sells a res mancipi, as can be seen in the texts of Cicero (where Atticus sells land), Plautus (where the young Persian sells a slave) and, less clearly, the formula Baetica (where the slave Dama could be the one selling the slave or the land).

It goes without saying that the sources leave many other problems unanswered. It is not clear, for instance, whether the transfer of ownership in these cases took place through mancipatio or through traditio. It is therefore unknown what the relationship between satisdatio and repromissio secundum mancipium and the responsibility for auctoritas rising from the mancipatio was, as well as the relationship with the stipulatio duplae. Accordingly, the very words "secundum mancipium" appear obscure, since they could either mean that the satisdatio or repromissio took place "after" the mancipatio or "according to [the liability rising from] the mancipatio". ${ }^{31}$ These are some of the problems that Roman law scholars have attempted to unveil, as will be shown in the following section.

\section{Repromissio and satisdatio secundum mancipium in modern scholarship}

One of the most widespread theories regarding the role of the satisdatio and repromissio secundum mancipium during the twentieth century, which was upheld - among others - by Arangio-Ruiz, ${ }^{32}$ claimed that these sureties were granted by the mancipio dans after the mancipatio had taken place, and that the stipulation had the same content of the liability for auctoritas. This had the purpose of making it possible to guarantee the obligation of auctoritas, since the sponsio and fideipromissio could only guarantee a verborum obligatio, which was not the case of the responsibility for auctoritas. It would therefore be natural to grant at least a repromissio alongside the mancipatio, in order to make it possible to secure it. Ankum has questioned this theory, claiming that the mere repromissio would appear to be useless, since only the satisdatio would achieve the role of granting further protection to the buyer. ${ }^{33}$ To this he adds that these sureties would have become irrelevant after the fideiussio made it possible to guarantee all kinds of obligations, which contradicts the survival of the satisdatio through the classical period. ${ }^{34}$ Moreover, one may add that if a repromissio

30 This contradicts the claim of Calonge 1968: 26-27, according to whom these sureties disappeared after the introduction of the stipulatio duplae.

31 Lenel 1927: 547.

32 Arangio Ruiz 1954: vol 2 329-332. Similarly, Lenel 1927: 546-547.

33 Ankum 1981: 749.

34 Idem at 749-750. 
or satisdatio would have been concluded almost by default alongside the mancipatio, one could expect the sources to give a more generous account regarding them.

Bechmann and Girard ${ }^{35}$ agree that the satisdatio and repromissio could serve the purpose of reinforcing the mancipatio, which would have been its original role. According to Girard, once the fideipromissio became widespread, the satisdatio secundum mancipium implied that the seller offered fideiussores, without having to grant himself an additional stipulation for that purpose.$^{36}$ However, these scholars add that the satisdatio and repromissio would also be granted when the seller could not mancipate, or when there were serious doubts that the seller would be responsible for the auctoritas when performing the mancipatio. Accordingly, the satisdatio and repromissio would have offered a liability for eviction in replacement of the liability for auctoritas which would follow from the mancipatio, reproducing the content of such liability. ${ }^{37}$ However, none of these authors specifies in which cases of failed or risky alienation these sureties would be granted, as noted by Ankum. ${ }^{38}$ Such broad scope of application would completely overlap with that of the stipulatio duplae, ${ }^{39}$ as will be shown below.

Another theory has been set forth by Meylan, who claims that these institutions were granted as a surety that the mancipated land was handed over, along with the fruits it had borne after the mancipatio..$^{40}$ Despite the praise deserved by Meylan's arguments, this theory has been abandoned on account that it contradicts the sources - which relate these sureties to the responsibility for eviction, and do not restrict them to the sale of land - and that it relies on extensive claims of interpolation within the Digest. ${ }^{41}$

Hans Ankum has offered the most comprehensive analysis of the sources on the subject ${ }^{42}$ which has remained unchallenged for several decades. According to the Dutch scholar, the satisdatio and repromissio secundum mancipium are always mentioned in contexts where the mancipatio cannot validly transfer ownership, which implies that these sureties were granted when the seller could only perform the traditio, offering the buyer to respond in case of eviction in the same way as if the mancipatio was performed. Ankum points out that almost every text on the subject explicitly mentions the intervention of an agent who transfers ownership over a res

35 Bechmann 1876: 369-374; Girard 1923: 41, 56-65.

36 Bechmann 1876: 369; Girard 1923: 61.

37 Girard 1923: 61-62. Calonge 1968: 20-24 offers a more restricted view, claiming that these sureties were granted in abnormal cases where the mancipatio did not give rise to the liability for auctoritas.

38 Ankum 1981: 752.

39 Meylan 1948: 4

40 Idem at 1-35, followed by Sargenti 1962: 160-164 and Mostert 1969: 24-56.

41 Amirante 1951: 340-344; Arangio-Ruiz 1954: 331-332; Calonge 1968: 20-21; Ankum 1981: 754755, 773-774.

42 Ankum 1981: 739-792; Ankum 2013: 13-28. 
mancipi ${ }^{43}$ something which he regards as crucial information since agents could not mancipate. ${ }^{44}$ This sole circumstance would therefore show that the satisdatio and repromissio did not take place after the mancipatio, but rather served the purpose of making the seller who performed the traditio liable in the same way as if he had mancipated. Ankum moreover shows that there are other circumstances which would have stood in the way of a valid mancipatio in the different cases discussed in the sources, such as the fact that the young Persian was a peregrinus, or that the land of the formula Baetica probably did not have the ius Italicum. ${ }^{45}$ All of this confirmed that these sureties would have been granted when someone could not perform the mancipatio over a res mancipi: since he could not mancipate, he would bind himself to praestare auctoritatem just as if the mancipatio had taken place. Later Ankum would add that these sureties could simply replace the mancipatio when it was unpractical or undesirable to resort to this mode of transferring ownership. ${ }^{46}$

Since several texts regarding these sureties involve the intervention of an agent, Ankum further claims that the praetor would have compelled the agent who sold a res mancipi to grant a satisdatio secundum mancipium, which would accordingly be a stipulatio praetoria included in his Edict in addition to other cautiones. ${ }^{47}$ According to Ankum, the seller needed to grant a satisdatio secundum mancipium when an agent conveyed a res mancipi because the buyer would find himself in a riskier position than if he had bought from the owner himself ${ }^{48}$ since the latter may not recognise the validity of the sale. The only thing standing in the way of a claim by the owner would be that the agent acted according to the instructions of the dominus negotii, something which would normally remain beyond the buyer's knowledge. It should be noted that Ankum's argument on this point is so compelling that subsequent scholars reproducing his ideas have simply indicated that the satisdatio and repromissio secundum mancipium served the purpose of giving a surety when an agent transferred ownership over a res mancip $i^{49}$ without indicating - to Ankum's distress $^{50}$ - that these sureties would have been granted whenever a res mancipi could not validly be mancipated.

As already mentioned before, Ankum offers a more comprehensive interpretation of the sources on the subject than any scholar before him. There is, however, one point in his construction which is highly debatable: when being confronted to the

43 Ankum 1981: 788-790.

44 Idem at 790; Ankum 2013: 18.

45 Ankum 1981: 758-761; Ankum 2013: 16. The observation regarding the formula Baetica is, however, far less compelling, since the author himself acknowledges (Ankum 1981: 788 n 159; Ankum 2013: $14 \mathrm{n}$ 7) that this formula must have been the copy of a Roman or Italic model.

46 Ankum 2013: 18.

47 Ankum 1981: 768-773, 790-792; Ankum 2013: 16-17.

48 Ankum 1981: 791-792, followed by Guida 2013: 69.

49 Ernst 1995: 7 n 3; Finkenauer 2010: 49.

50 Ankum 2013: 13. 
question of whether the satisdatio and repromissio were granted when a mancipatio or a traditio took place, Ankum chose the latter option. This choice is motivated by the preconception that an agent could not mancipate, an idea that has recently been subject to intense criticism, as shown in the following section. Moreover, the scope granted by Ankum to these sureties raises relevant problems regarding the overlap between these institutions and the stipulatio duplae, as well as with the exceptio rei venditae et traditae. These objections will be reviewed in the following sections, showing that it is much more likely that the satisdatio and repromissio secundum mancipium were sureties against eviction granted by the agent who performed a mancipatio, not a traditio.

\section{Mancipatio by an agent}

Once Ankum realised that the satisdatio and repromissio secundum mancipium were often granted in the context of the sale by an agent, he jumped to the conclusion that these institutions could not take place after a mancipatio, since agents could not validly mancipate. This claim was widespread among Roman law scholars since the nineteenth century. However, it has been shown elsewhere that the idea of a ban on agency regarding the mancipatio is an inheritance of a nowadays obsolete reconstruction of the development of agency in Roman law. ${ }^{51}$ According to traditional German scholarship, the ius civile originally banned every form of direct representation, which is why no actus legitimus could be performed through an agent. The Roman jurists would have overcome this prohibition in the course of time in various ways - such as the actiones adiecticiae qualitatis - which would in turn be a valuable lesson for the nineteenth century German jurists: if the Roman jurists had already abandoned the primitive ban on direct representation to a large extent, the classical rules such as alteri stipulari nemo potest should not prevent the acceptance of a general notion of Stellvertretung in Germany. ${ }^{52}$

Despite the practical scope of this theory, it was an immediate success among Roman law scholars. One of the most ardent defenders of this reconstruction was Ludwig Mitteis, who devoted considerable efforts to discard that an agent could carry out actus legitimi such as a mancipatio or a manumissio vindicta. ${ }^{53}$ Ankum himself followed his footsteps in contributions where he discards that slaves could mancipate ${ }^{54}$ even when Ankum wrote that it was already clear that several actus legitimi could indeed be concluded by an agent. In fact, Ankum struggles to find a legal ground for the impossibility of a slave to mancipate, ${ }^{55}$ which makes it even

51 Rodríguez Diez 2016: 223-264; Rodríguez Diez 2017: 62-80.

52 See, on this evolution, Rodríguez Diez 2017: 64-67.

53 Mitteis 1908: 203-213.

54 Ankum 1978: 1-18; Ankum 1984: 5-17.

55 Ankum 1978: 13. 
more arguable that later, when discussing the satisdatio and repromissio secundum mancipium, he goes so far as to claim that no agent - slave or free-could mancipate, quoting only a couple of general textbooks to support such broad statement. Contrary to these traditional conceptions, it has been shown that the evidence in the sources strongly suggests that an authorised non-owner could indeed transfer ownership through mancipatio or in iure cessio..$^{56}$ This makes it even more urgent to revisit the idea that the satisdatio and repromissio secundum mancipium could only be granted by an agent in the context of a traditio. ${ }^{57}$

\section{Stipulatio duplae and the repromissio or satisdatio secundum mancipium}

As pointed out above, Ankum opines that the satisdatio and repromissio would have been granted when someone could not perform the mancipatio over a res mancipi, the most common case being the alienation by an agent. However, such theory as well as those of Bechmann and Girard - faces an immediate challenge: if this would have been the scope of application of these sureties, it would completely overlap with that of the stipulatio duplas ${ }^{58}$ which was granted for the sale of res mancipi delivered by traditio. ${ }^{59}$ The satisdatio and repromissio would, moreover, have become irrelevant after jurists admitted - in the course of the second century $\mathrm{AD}$ - that the seller was liable for eviction even if no stipulation was concluded. ${ }^{60}$ It should, moreover, be noted that this liability also bound the agent who sold and transferred ownership, whether the delivered object was a res mancipi or not. ${ }^{61}$

Ankum is aware of the overlap between the satisdatio and repromissio and the other grounds of liability for eviction, which is why he points out that the role of the satisdatio and repromissio in legal practice was not too relevant. ${ }^{62}$ This is an understatement; if the overlap was such, the satisdatio and repromissio secundum mancipium simply could not have coexisted with the stipulatio duplae for several centuries. If the satisdatio and repromissio were indeed the first verbal sureties

56 Corbino 1976: 50-71; Corbino 1984: 2257-2271; Coppola Bisazza 2008: 100-110, 283-290; Rodríguez Diez 2016: 223-264.

57 Rodríguez Diez 2017: 71.

58 This point was already raised by Meylan 1948: 4 (followed by Mostert 1969: 27 n 146) when criticising the theories of Bechmann and Girard.

59 See, on this point, Dalla Massara 2007: 293-296 and Guida 2013: 87-90, with further references.

60 See Dalla Massara 2007: 297-310 and Guida 2013: 116-136, with further references.

61 FV $328=$ D 33 67; D 62 14; D 171 49. The same can be said when the agent sells and grants a caution, as shown in D 1911325 (“Si procurator vendiderit et caverit emptori ..."). See, on these texts, Rodríguez Diez 2016: 98-100.

62 Ankum 2013: 18: "Übrigens darf man die Wichtigkeit der r.s.m. und der s.s.m. nicht überschätzen, wenn man sich die wichtige Rolle der auf der stipulatio duplae basierenden actio ex stipulatu und seit Pomponius und Julian der actio empti in Eviktionsfällen bewusst ist." 
for eviction in the context of a sale of res mancipi, one could wonder, in the first place, how the stipulatio duplae could have later emerged as a separate stipulation. Moreover, one could expect that the satisdatio and repromissio would have had a very relevant role in early classical Roman law, as the traditio of res mancipi became increasingly common, and that accordingly the sources would reflect the importance of these institutions. Finally, if the stipulatio duplae somehow displaced these older sureties, one could in fact expect that the satisdatio and repromissio would have disappeared completely after the stipulatio duplae was introduced, or at any rate after the actio empti encompassed the responsibility for eviction.

Considering the above circumstances, it seems unlikely that the satisdatio and repromissio secundum mancipium had a role in Roman law as sureties given whenever a res mancipi could not be conveyed through mancipatio, as claimed by Ankum.

\section{Exceptio rei venditae et traditae and the satisdatio secundum mancipium}

The role of the satisdatio secundum mancipium as a stipulatio praetoria described by Ankum would moreover overlap with the scope of the exceptio rei venditae et traditae, which had the precise scope of repelling the Quiritary owner who sought to recover a res mancipi delivered by traditio. Since the buyer would be protected by the praetor, an additional surety granted by the seller with this specific aim would seem pointless. Moreover, this exceptio was granted to the acquirer who obtained a res mancipi by traditio from an agent, as shown in the following text by Ulpian:

D 2131 2-3 (Ulp 76 ed): (2) Si quis rem meam mandatu meo vendiderit, vindicanti mihi rem venditam nocebit haec exceptio, nisi probetur me mandasse, ne traderetur, antequam pretium solvatur. (3) Celsus ait: si quis rem meam vendidit minoris quam ei mandavi, non videtur alienata et, si petam eam, non obstabit mihi haec exceptio: quod verum est. (2) If someone, acting on my mandate, sells a thing belonging to me, I shall be defeated by this defence in the event that I seek to assert title to it after the sale; unless it be proven that my mandate was that the thing should not be delivered until the full price had been paid. (3) Celsus says that if my mandatary has sold a thing of mine at a price lower than that which I specified, the thing is deemed not to have been alienated; and so if I claim the thing as mine, this defence will not lie against me; this is correct [trl Thomas/Watson, modified].

The text has been analysed in further detail elsewhere, ${ }^{63}$ but for the purpose of this article it is worth noting that it poses the problem of whether the buyer can resort to the exceptio rei venditae et traditae ${ }^{64}$ if an agent, acting as the seller, did not transfer ownership. In the case described in D 21312 we are not told why Quiritary

63 Rodríguez Diez 2016: 197-199.

64 Lenel 1889: vol 2 col 860. 
ownership is not transferred, but the fact that Ulpian was discussing the alienation of land (D $2131 \mathrm{pr}-1$ ) suggests that the underlying reason was that the agent performed a traditio over a res mancipi. Under these circumstances, if the agent acts within the instructions of the owner, the buyer will be able to oppose to the latter's claim the exceptio rei venditae et traditae. In other words, the most common application of this exceptio - to repel the owner of a res mancipi that was conveyed through traditio - also applied to the case where the delivery was performed by an authorised non-owner. If, however, the agent did not comply with the owner's instructions, as reported in D 21313 , this defence would be of no avail. ${ }^{65}$

Considering the scope of the exceptio rei venditae et traditae, it seems unlikely that the authorised non-owner would be compelled to give a special surety when performing a traditio over a res mancipi in order to secure the buyer against a claim from the owner. At any rate, if that would have been the original role of the satisdatio and repromissio secundum mancipium, these sureties would have become irrelevant and disappeared at an early stage of the classical period.

\section{The satisdatio and repromissio as sureties for eviction at the mancipatio by an agent}

The overlap between the scope granted by Ankum to the satisdatio and repromissio secundum mancipium and other institutions of classical Roman law strongly suggests that these sureties did not aim at protecting the buyer who acquired a res mancipi by traditio. It seems more likely that these sureties were granted in the context of the mancipatio by an agent. First, all the texts concerning the satisdatio and repromissio refer to the transfer of ownership over a res mancipi. In this context, it would seem odd that the expression "secundum mancipium" would not refer to a stipulation which took place after a mancipatio ${ }^{66}$ Second, most of the sources record the intervention of an authorised non-owner ${ }^{67}$ Moreover, such scope of application of these sureties agrees with their place within the sources. The fact that these institutions are mentioned very few times over a span of several centuries - from Plautus to the Iuridicarum vocum explanatio - agrees well with the possibility that they were granted in the context of the mancipatio, which was around for a long time but regarding which we have fragmentary information in the sources. Since there are

65 See, moreover, D 2131 5, which is analysed in Rodríguez Diez 2016: 199-201.

66 Lenel 1927: 547; Sargenti 1962: 156.

67 Leaving aside some exceptional cases (eg D 212 76; D 19111 8-9; D 19113 17), most texts preserved within the Digest are less explicit on this point, which is no wonder, considering that the compilers drew the texts from their original contexts. This makes it impossible to determine in what role the venditor acted. 
few accounts of mancipationes performed by an agent, ${ }^{68}$ it is no wonder that only very few texts dealing with the satisdatio and repromissio secundum mancipium have survived.

The fact that these sureties most likely had a role to play when an agent mancipated, however, leaves the problem of the exact role of the satisdatio and repromissio unsolved. Regarding the satisdatio secundum mancipium, part of Ankum's theory remains valid, namely that a cautio was necessary to secure a buyer who was in a risky position. Various sources show that a non-owner who was authorised by the owner could validly transfer ownership. ${ }^{69}$ When doing so, he could either act on behalf of the owner (nomine alieno) or not (nomine proprio). ${ }^{70}$ If the agent acted nomine alieno, the buyer would know that the transfer of ownership would depend on the owner's intent, which was a rather volatile element. The owner could change his mind or die, which would stand in the way of the transfer of ownership..$^{71}$ The same thing can be said if the agent did not abide to the specific instructions of the owner, ${ }^{72}$ which would normally be unknown to the buyer. In short, the buyer who knowingly bought from an agent faced a series of relevant threats, which is why he would be interested in having a greater surety from the seller in the form of a satisdatio.

While the satisdatio secundum mancipium would have only been applicable to the mancipatio performed by an agent, it is interesting to note that the sources report a similar cautio which could be given to the buyer by an agent:

D 46810 (Ulp 80 ed): Interdum ex conventione stipulatio ratam rem interponi solet, ut puta si quid procurator aut vendat aut locet aut si ei solvatur.

A stipulation for ratification is sometimes interposed by agreement, for instance, if a procurator sells or lets something or if performance be made to him.

D 46811 (Hermog 6 iuris epitomarum): Vel paciscitur vel quodlibet aliud nomine absentis gerit.

Or if there be an agreement [not to sue] or anything be done by him in the name of one not present.

D 46812 pr (Ulp 80 ed) Quo enim tutiore loco sit, qui contrahit de rato solet stipulari.

Whereby his position will be more secure, the contracting party usually stipulates for ratification [trl Beinart/Watson].

68 Rodríguez Diez 2016: 228-257. The need to resort to an agent in order to mancipate must have been less pressing than regarding the traditio, since the mancipatio over land could be concluded at a distance (Gai 1 121: "praedia vero absentia solent mancipari").

69 Rodríguez Diez 2016: 53-56, 63-73. D 212391 suggests that the same seems to have been the case concerning the mancipatio, as shown in Rodríguez Diez 2016: 243-252.

70 Rodríguez Diez 2016: 128-136.

71 Idem at 73-80.

72 Idem at $111-114$ 
This group of texts deals with the cautio rem ratam haberi, which is normally found in the context of procedural representation. As these texts show, this cautio could also play a role outside the procedure ${ }^{73}$ as would be the case when the agent sells (D 468 10) or performs any other act on behalf of the dominus negotii (D 468 11) and the other party wants to have a surety regarding the owner's intent (D 46812 pr). Under such conditions, we are told that the cautio rem ratam haberi is "usually" (solet) granted. However, the sources do not report specific cases where this cautio was granted by an agent when transferring ownership, which is why one may assume that this surety was far from indispensable, perhaps being only granted when the owner had given no instructions whatsoever and the acts of his procurator needed his ratification to be valid.

These texts are particularly relevant for the satisdatio and repromissio secundum mancipium since the latter institutions - along with the responsibility for auctoritas - were dealt in the Edict immediately after the cautio rem ratam haberi. ${ }^{74}$ It therefore seems plausible that the satisdatio and repromissio secundum mancipium fulfilled a similar practical role to the cautio rem ratam haberi in the context of a mancipatio by a non-owner, granting the acquirer a surety in the context of the acts of an agent. ${ }^{75}$ This would, moreover, agree with Lenel's theory concerning the location of the actio auctoritatis and the satisdatio secundum mancipium within the Edict, since the later subject would have been brought close to another satisdatio which had a similar practical role.

\section{D 212391 and the surety granted by "your slave"}

As already shown, scholars claim to have identified numerous texts within the Digest which would have originally been referred to the satisdatio or repromissio secundum mancipium. Such texts have often been used to map some of the features of these institutions, as well as the liability which arose from them. Besides being plagued by the uncertainties inherent to the unveiling of interpolated texts, this careful analysis has not offered further information on the exact role of these sureties. There is, however, a text by Julian that may offer key information in this regard:

D 212391 (Jul 57 dig): Si servus tuus emerit hominem et eundem vendiderit Titio eiusque nomine duplam promiserit et tu a venditore servi stipulatus fueris: si Titius servum petierit et ideo victus sit, quod servus tuus in tradendo sine voluntate tua proprietatem hominis transferre non potuisset, supererit Publiciana actio et propter hoc duplae stipulatio ei non committetur: quare venditor quoque tuus agentem te ex stipulatu poterit doli mali exceptione summovere.

73 Finkenauer 2010: 216.

74 Lenel 1927: 541-542.

75 Similarly Ankum 1981: 791. It should, however, be noted that the scope of the satisdatio and repromissio secundum mancipium must have been to secure the buyer against eviction in general, and not only against the claim of the dominus negotii. 


\begin{abstract}
Alias autem si servus hominem emerit et duplam stipuletur, deinde eum vendiderit et ab emptore evictus fuerit: domino quidem adversus venditorem in solidum competit actio, emptori vero adversus dominum dumtaxat de peculio. Denuntiare vero de evictione emptor servo, non domino debet: ita enim evicto homine utiliter de peculio agere poterit: sin autem servus decesserit, tunc domino denuntiandum est.
\end{abstract}

Suppose that your slave has bought a slave, whom he sells to Titius, promising double the price in the event of eviction, while you have stipulated similarly from the vendor of the slave. If Titius were to claim the slave and be unsuccessful because your slave has not been able to transfer the ownership of the slave since he delivered it without your consent, the actio Publiciana remains, and so the stipulation for double will not become enforceable; hence also, your own vendor can defeat you with the exceptio doli if you sue him on the basis of the stipulation. But the situation is different if the slave has bought a slave and has made a stipulation for double, and subsequently sold the slave and it was evicted from the buyer; the owner of the slave [i.e. the owner of the slave that bought and sold Stichus] will have action for the total amount against the seller, but the buyer will have action against the owner only to the extent of his peculium. The buyer must, however, give notice of the eviction to the slave, not to his master; for then, the eviction taking place, he can effectively sue to the extent of the peculium; should the slave now be dead, however, he can give notice to the master [trl Thomas/Watson, modified].

Julian describes two different cases, involving six characters: ${ }^{76}$ (1) "you", the owner of a slave who trades; (2) "your slave", who buys and sells other slaves; (3) a slave who is bought and sold by "your slave", whom we can name "Stichus" to avoid confusion; (4) the original vendor who sold Stichus to "your slave", whom we will call "Seius"; (5) Titius, who buys from "your slave"; (6) and a claimant who takes Stichus from Titius, hereafter "Maevius". In both cases "your slave" grants a stipulatio duplae. In none of the cases described is Quiritary ownership over Stichus transferred to Titius: In the first case, because "your slave" acts without your consent ("sine voluntate tua"); and in the second case, because Seius was not the owner of Stichus.

The failure to transfer ownership to Titius leads to a series of consequences concerning subsequent legal claims. In the first case, Titius attempts to reivindicate Stichus and fails, since he did not acquire Quiritary ownership in the first place. However, Titius could successfully exercise the actio Publiciana, which shows that Maevius was not his owner. Since Titius had a better right than Maevius and may therefore resort to the Publiciana, he has not lost the habere licere, ${ }^{77}$ which is why

76 The case and the theories built around it are described in further detail in Rodríguez Diez 2016: 243-252.

77 Kaser 1970: 483; Ankum 2002: 233, 235; Cristaldi 2007: 214; Coppola Bisazza 2008: 109; Guida 2013: 85-87, 164-165. Daube 1960: 110, however, assumes that the text is corrupted at this point, since the delivered object would become a res furtiva. However, not any conveyance invito domino rendered the delivered object a res furtiva, and even if this was the case, the impossibility to acquire through usucapio did not exclude the possibility to resort to the Publiciana. See, in this regard, Rodríguez Diez 2016: 80-98, 247. 
he will not be able to make "you" liable on account of the stipulatio duplae. This in turn implies that if "you" seek responsibility from Seius, "you" will be defeated with an exceptio doli. In the second case, Maevius would be the owner of Stichus, which is why Titius would completely lose the habere licere and would therefore be able to claim responsibility from "you". "You" will, in turn, be able to successfully seek responsibility from Seius.

This text has been considered by most scholars to have dealt originally with the mancipatio of a slave. ${ }^{78} \mathrm{~A}$ strong indication is its location within the Edict, alongside other texts which Lenel groups under the rubric "De auctoritate". ${ }^{79}$ However, the fact that the text originally dealt with two successive mancipationes would imply that a slave could mancipate, something which has been traditionally rejected, as already pointed out above. This, in turn, has led scholars to claim that the text is severely corrupted ${ }^{80}$ since the very ground of the decision would have been altered. Against this traditional opinion, it has been argued that the content of the solution is classical, since the owner's authorisation (voluntas domini) was indeed required for the transfer of ownership by a non-owner, both in the mancipatio and in the traditio. ${ }^{81}$ Since the ground of the decision was common to both modes of transferring ownership, it would have made sense to the compilers to preserve the text by introducing mechanical interpolations. Therefore, the text appears as one of the clearest cases of a mancipatio performed by a non-owner.

If Julian indeed dealt with the mancipatio by an agent, the references to the traditio and the stipulatio duplae in the text would be the result of the mechanical interpolations. Accordingly, it could appear that the responsibility described in the two subsequent sales - between Seius and "you", and between "you" and Titius - would correspond to the auctoritas which rises from the mancipatio, and that accordingly no stipulation whatsoever was concluded. However, a careful analysis of the text shows that the liability of the subsequent sellers cannot have the same ground, since the features of "your" liability towards Titius are completely different to those of Seius' liability towards "you". In fact, the whole text revolves around the problem of the stricter liability between Seius and "you" than between "you" and Titius, which in principle enables "you" to sue Seius even if Titius cannot hold "you" liable. First, Titius can only hold "you" liable to the extent of the peculium granted to your slave ("emptori vero adversus dominum dumtaxat de peculio"). "You", on the other hand, can sue Seius for the whole amount ("domino quidem adversus venditorem in

78 See, on this point, Brägger 196-197 with further references.

79 Lenel 1889: vol 1 col 463-464; Lenel 1927: 545.

80 Among the various attempts of reconstruction, see Mitteis 1908: 208-209; Girard 1923: 224-226; Daube 1960: 110-114; Kaser 1970: 481-490; Corbino 1976: 53-60; Ankum 1978: 6-10; Ankum 1979: 38-40; Ankum 1984: 11-16; Ankum 2002: 231-235; Reduzzi Merola 2004: 316-321; Cristaldi 2007: 210-214; Coppola Bisazza 2008: 103-110; and Finkenauer 2010: 82-86.

81 Coppola Bisazza 2008: 107-110; Rodríguez Diez 2016: 243-252. 
solidum competit actio"), which agrees with the indivisible nature ("in solidum") of the obligation of auctoritas. While this difference can be explained on the ground of the intervention of an agent, it should moreover be noted that the underlying fact which triggers the liability of the seller is different regarding "your" claim and Titius' claim. On the one hand, Titius can only hold "you" liable if he loses the habere licere; otherwise the stipulation will not become enforceable ("duplae stipulatio ei non committetur"). "You", on the other hand, can seek liability from Seius for the sole fact that Titius did not become Quiritary owner. The praetor, however, remedies the stiffness of the actio auctoritatis by granting Seius an exceptio doli against "you" if Titius has not completely lost the habere licere ("venditor quoque tuus agentem te ex stipulatu poterit doli mali exceptione summovere"). ${ }^{82}$

While "your" claim appears to be grounded on Seius' obligation of auctoritas, one must determine which was the ground of the more limited liability sought by Titius against "you". In order to do so, one can also exclude that "your slave" simply delivered Stichus by traditio. ${ }^{83}$ If that was the case, the ground for the failed transfer of Quiritary ownership would be the delivery of a res mancipi through traditio instead of mancipatio, and therefore the lack of authorisation of the agent ("servus tuus in tradendo sine voluntate tua") would be completely irrelevant. More importantly, it would be unconceivable that Titius would have resorted to the rei vindicatio in the first place, thereby believing to be Quiritary owner. ${ }^{84}$

As claimed above, the satisdatio or repromissio secundum mancipium were used when an agent mancipated, which makes them the most likely ground for liability between "you" and Titius for the mancipatio concluded by "your slave". 85 The possibility that the slave concluded a stipulatio duplae, as claimed by Girard and Ankum, ${ }^{86}$ appears much more unlikely, not only on account of the palingenetic analysis of the text, ${ }^{87}$ but also because of the very restricted role that such stipulation appears to have had in the context of the transfer of ownership by mancipatio. ${ }^{88}$

82 Girard 1923: 225, 228-229; Daube 1960: 110-112; Kaser 1970: 488-489; Ankum 1979: 39; Brägger 2012: 198-200; Rodríguez Diez 2016: 248-250.

83 Such is the claim of Kaser 1970: 486 and Reduzzi Merola 2004: 320-321.

84 Daube 1960: 110; Ankum 2002: 233 n 16.

85 Since the text describes that the seller "promises" double the price (duplam promiserit), it could suggest that it originally dealt with a repromissio secundum mancipium. However, since the content of the satisdatio and repromissio secundum mancipium appears to have been the same, the point is not decisive.

86 Girard 1923: 224-226; Ankum 1978: 8; Ankum 1979: 40.

87 Julian dealt with the actio auctoritatis in book 57 of his Digesta. Moreover, the other text which Lenel located in Julian's book 57 of his Digesta (D 21251 1, where Ulpian quotes Julian) would refer, according to this author, to the repromissio or satisdatio secundum mancipium (Lenel 1889: vol 1 col 464 n 7). Brägger 2012: 90, on the other hand, refers this text to the actio auctoritatis.

88 As shown in the following section, only in exceptional cases do the sources report that a stipulation for eviction was concluded alongside a mancipatio, which is almost always a stipulatio simplae. 
Accordingly, D 212391 seems to offer the most detailed account on the practical consequences of the satisdatio or repromissio secundum mancipium, and thus merits a detailed analysis.

Perhaps the most revealing consequence which follows from this text is that the slave who mancipated could not make his owner liable for auctoritas. ${ }^{89}$ If that was the case, the features of the liability between "you" and Seius would be the same as those between Titius and "you". Moreover, if "your slave" could in some way give rise to this liability, one could wonder why Titius would settle for the more limited liability described by Julian.

The lack of auctoritas following the mancipatio by "your slave" seems to hold the key to the role of the satisdatio and repromissio secundum mancipium: these sureties did not have the purpose of merely reinforcing an existing liability; they constituted the source of the liability for eviction themselves. The only way in which "your slave" could make "you" liable was through a satisdatio or repromissio. In other words, the primary role of the satisdatio or repromissio would be to create a ground for liability for the seller mancipio dans in a context where he could not be held liable for the auctoritas. ${ }^{90}$ However, D 212391 shows that these sureties did not give rise to the obligation with an identical content to the statutory liability for auctoritas, ${ }^{91}$ as it had been claimed by Ankum. ${ }^{92}$ Accordingly, the expression "stipulatio auctoritatis" of the Fragmenta Vaticana, must be the consequence of a rather vulgar use, ${ }^{93}$ as shown below. The same could be said regarding the rubric "De contrahenda auctoritate" in the Pauli Sententiae $510 .{ }^{94}$ One should, moreover, not exclude that the term "auctoritas" could be used in a rather promiscuous fashion when discussing the responsibility for eviction in these texts..$^{95}$

89 This was already claimed by Girard 1923: 225-226 and 228-229; Ankum 1978: 8. However, this is based on the assumption that the mancipatio by a slave would neither transfer ownership nor make the owner liable for auctoritas, which is why these scholars consider that "your slave" would have resorted to the stipulatio duplae.

90 Such an opinion was briefly set forth by Calonge 1968: 21-24

91 Lenel 1927: 547; Sargenti 1962: 156; Calonge 1968: 24.

92 Ankum 1981: 790; Ankum 2013: 14-15. Nonetheless, the author indicates that these sureties would grant the buyer an actio ex stipulatu against the seller, not an actio auctoritatis (or de auctoritate)

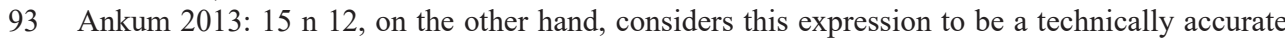
equivalent to the repromissio secundum mancipium.

94 See, on this text, Lenel 1927: 548; Ankum 1981: 764-765. The same reference to the auctoritas of the seller is made in PS 217 1, discussed by Ankum 1981: 765-767. However, whether the rubric of PS 510 indeed refers to the repromissio or satisdatio secundum mancipium is arguable on account of the observation of Girard 1923: 204 n 2 (followed by Meylan 1948: 7) that the expression "auctoritas contrahere" appears to refer, above all, to the liability of auctoritas that follows the mancipatio.

95 For the scope of the terms "auctor" and "auctoritas" in the context of the transfer of ownership, see Brägger 2012: 29-39. Meylan 1948: 7-8 and Guida 2013: 61 are sceptical regarding the significance of PS 510 and FV 10 in relation to the repromissio or satisdatio secundum mancipium. 
Returning to D 21239 1, it should be noted that the mechanics surrounding the denuntiatio of Titius appear to agree with these conclusions. If the mancipatio performed by "your slave" would give rise to liability for auctoritas, certainly "you" would be the auctor and, as such, the person to whom Titius should make the laudatio auctoris. ${ }^{96}$ However, Julian indicates that, as long as it was possible, the denuntiatio had to be made to the slave. This not only agrees with the fact that he is the most suitable person to provide the necessary information concerning the title, but also the effective party to the stipulation. ${ }^{97}$ Just as in the stipulatio duplae, the claim following from the stipulation would only be in place if the buyer first made a denuntiatio against the seller." "Your" responsibility is therefore not the one of an auctor, ${ }^{99}$ but merely of a dominus who responds for the stipulations of his slave to the extent of the peculium granted to him.

The fact that these sureties would constitute the only source of liability for the seller - and not reinforce an already existing obligation - would moreover explain the very existence of the repromissio secundum mancipium. It has been justly pointed out that it is rather difficult to explain that the seller should stipulate for eviction after concluding a mancipatio (without giving guarantors), since there would seem to be a double - and redundant - ground to hold the seller liable: the auctoritas and the repromissio. ${ }^{100}$ In this context, only the existence of a satisdatio secundum mancipium would make sense, since an additional personal security would strengthen the position of the buyer. The repromissio, on the other hand, would be unnecessary. The answer to this problem is that there is not a double ground for liability, since the mancipatio concluded by an agent would not give rise to the actio auctoritatis, which is why the agent had to conclude a special repromissio or satisdatio.

\section{Mancipatio with stipulation for eviction and auctor secundus in Roman legal practice}

The role of the satisdatio and repromissio secundum mancipium as sureties for the mancipatio concluded by an agent may contribute to understanding some elements of legal practice which have been neglected when analysing these institutions. Of special significance are several surviving documents regarding the sale of a res mancipi or valuable res nec mancipi where the parties are said to have sold and

96 See, on this point, Ankum 2014: 2-6.

97 Daube 1960: 114; Kaser 1970: 490.

98 Ankum 2014: 7-11.

99 Brägger 2012: 91: "Die Ausnahme, das im Falle des Verkaufs durch einen Sklaven die denuntiatio an diesen und nicht an den dominus zu erfolgen habe, galt somit bei der auctoritas nicht. Sie kam zur Anwendung, wenn der Käufer sich auf eine andere Anspruchsgrundlage stütze (stipulatio duplae oder actio empti)."

100 Meylan 1948: 3-4; Sargenti 1962: 155; Mostert 1969: 27-28 n 146; Ankum 1981: 749-750, 788790; Dalla Massara 2007: 285-286. 
mancipated ("emit mancipioque accepit") and, moreover, that the seller granted a stipulation against eviction. ${ }^{101}$ Scholars tend to agree nowadays that such reference to a mancipatio corresponds to a "degenerate" usage, which - at least in provincial practice - would not grant Quiritary ownership to the acquirer. ${ }^{102}$ Nonetheless, such practice is also attested in one document from Herculaneum, ${ }^{103}$ which shows that we are not dealing exclusively with a provincial abnormality.

From the point of view of the liability for eviction, the use of a stipulation for eviction alongside the mancipatio is fairly odd. ${ }^{104}$ When a mancipatio was concluded the seller would be liable for auctoritas ${ }^{105}$ which is why a stipulation for eviction seems completely out of place. However, the inclusion of a stipulation for eviction alongside a mancipatio can be related to the existence of the satisdatio and repromissio secundum mancipium, since the existence of such sureties must have made it more acceptable to include both elements in a deed of sale. Probably the main reason to replicate such usage, even when an agent did not intervene, was to seek a milder liability than the auctoritas. ${ }^{106}$ This may explain why almost every stipulation for eviction concluded alongside a mancipatio was a stipulatio simplae. ${ }^{107}$ Nonetheless, at some point the praetorian protection of the acquirer must have made it needless to mancipate, which is why the parties did not include the "mancipioque accepit"clause even when the number of witnesses would have been sufficient to perform a mancipatio. ${ }^{108}$ Such practice, however, remained in use in the provinces ${ }^{109}$ where

101 FIRA 1968: vol 3 283-284 (§ 87) (emptio puellae, AD 139); 285-286 (§ 88) (emptio pueri, AD 142); 287-288 (§ 89) (emptio ancillae, AD 160); 290 (§ 90) (emptio domus, AD 159); Tabula Fortunatae (first to second century AD), re-edited by Camodeca 2007: 397-404; $\mathrm{TH}^{2} 61$ (Camodeca 2017: 180-181) (63 AD). See Cristaldi 2007: 219-230 for the context of these texts and bibliographical references.

102 See Cristaldi 2007: 243-251 with further references, as well as Finkenauer 2010: 77-78 and Mattiangeli 2011: 307-323.

$103 \mathrm{TH}^{2} 61$ (Camodeca 2017: 180-181). For an outlook of stipulations for eviction in surviving documents from the classical period, see Camodeca 2017: 189-190.

104 On the coexistence of the mancipatio alongside a stipulation for eviction, see Ankum 1979: 27-30; and Cristaldi 2007: 251-255 with further references.

105 Brägger 2012: 47-52.

106 Ankum 1979: 29-30, followed by Cristaldi 2007: 254-254 and Brägger 2012: 50, 216-217.

107 Ankum 1979: 28-29. The only exception is FIRA 1968: vol 3 283-284 (§ 87), where the seller concludes a stipulatio duplae.

108 Koops 2014: 49-50 highlights that already in the year AD 166 the parties to a sale that resembles a mancipatio did not feel the need to include the clause "mancipio accepit", as seen in FIRA 1968: vol 3 425-427 (§ 132) (emptio pueri Seleuciae pieriae contracta). The same could be said of TPSulp 43 (38 AD), which however leads Camodeca 1987: 177-178 to assume that the mancipatio was performed anyway. Such conclusion seems debatable: since the "mancipioque accepit"-clause was already in use in Herculaneum at that time, it would seem curious not to include it when mancipating.

109 FIRA 1968: vol 3 283-284 (§ 87), 285-280 (§ 88), 6, 287-288 (§ 89), 290 (§ 90) correspond to the territory of ancient Dacia, and the sale of Fortunata (Camodeca 2007: 397-404) was concluded in Roman Britain. 
it had its own advantages: on the one hand, the reference to the mancipatio would attest that the seller conveyed in an utmost formal way, even when such conveyance did not transfer Quiritary ownership; on the other hand, if there was any reason to suspect the validity of the mancipatio, the seller would in any case be bound by the stipulation for eviction. ${ }^{110}$

There is another commercial practice which shows traces of the satisdatio and repromissio secundum mancipium: the widespread misconception that a seller who granted a stipulation against eviction over a res mancipi should moreover offer a personal security, an "auctor secundus". Classical jurists report that it was a common practice to grant such guarantors, but that it was by no means legally required. Ulpian reports the use of the vulgar expression "auctor secundus" ("volgo auctorem secundum vocant") to describe the guarantor who secures the seller against eviction in the sale of a slave, a security which he regards as not essential unless the parties have agreed otherwise ("[e]t est relatum non debere, nisi hoc nominatim actum est"). ${ }^{111}$ Scholars have often assumed from the use of the term "auctor" that this fragment was originally restricted to the mancipatio. ${ }^{112}$ However, as claimed by Meylan, ${ }^{113}$ the text is better understood in relation to D $21256 \mathrm{pr}$, where Paul - writing on the Edict of the aedile - reports that it was popular belief ("ut vulgus opinatur") that a cautio should be granted along with the stipulatio duplae, which he discards in the same terms as Ulpian ("sed sufficit nuda repromissio, nisi aliud convenerit"). ${ }^{114}$ Similarly, another text from Ulpian rejects the need for guarantors at the sale, ${ }^{115}$ as well as the Codex Iustinianus $43812 \mathrm{pr}$ ("Non idcirco minus emptio

110 Camodeca 1987: 177; Cristaldi 2007: 254; Brägger 2012: 49-50. Moreover, as noted by Cristaldi 2007: 250-251, the use of witnesses prescribed by the mancipatio would give more publicity to the sale.

111 D $2124 \mathrm{pr}$ (Ulp $32 \mathrm{ed}$ ): Illud quaeritur, an is qui mancipium vendidit debeat fideiussorem ob evictionem dare, quem volgo auctorem secundum vocant. Et est relatum non debere, nisi hoc nominatim actum est. (It has been asked whether one selling a slave ought to give a verbal guarantor against eviction, what might commonly be called a second guarantor of the purchase. The tradition is that this is not essential, unless the parties have specifically provided otherwise [trl Thomas/Watson]).

112 Lenel 1889: vol 2 col 630 and Ankum 1981: 789

113 Meylan 1948: 6 n 2, followed by Mostert 1969: 30-31 n 156.

114 D 21256 pr (Paul 2 ad edictum aedilium curulium): Si dictum fuerit vendendo, ut simpla promittatur, vel triplum aut quadruplum promitteretur, ex empto perpetua actione agi poterit. Non tamen, ut vulgus opinatur, etiam satisdare debet qui duplam promittit, sed sufficit nuda repromissio, nisi aliud convenerit. (If it be stated at the time of sale that a stipulation for once, triple or fourfold the price is to be entered into, an action on purchase will lie at any time. However, contrary to popular belief, one who promises double the price is not required to give security; a simple promise suffices unless the parties agree otherwise [trl Thomas/Watson]).

115 D 21237 pr (Ulp 32 ed): Emptori duplam promitti a venditore oportet, nisi aliud convenit: non tamen ut satisdetur, nisi si specialiter id actum proponatur, sed ut repromittatur. (The purchaser should receive the stipulation for double the price from the vendor, subject to a contrary agreement; but he is not entitled to security, unless that be specifically contracted for; he is entitled only to the promise [trl Thomas/Watson]). 
perfecta est, quod emptor fideiussorem non accepit"), while the Codex Iustinianus 66012 highlights that it is up to the buyer to ask for guarantors ("et emptori, si velit, fideiussorem licebit accipere").

These texts show that it was a widespread belief in commercial practice that the seller should offer guarantors for eviction at the sale - particularly of res mancipi - when a stipulation for eviction was granted, despite not being legally required. ${ }^{116}$ Such misconception can be explained on account of the existence of the satisdatio secundum mancipium, where the seller - provided he was an agent - would indeed be compelled to give a surety against eviction when selling a res mancipi. The widespread use of the satisdatio secundum mancipium in commercial practice must have led to the assumption that every sale of res mancipi involving a stipulation against eviction should be coupled with a personal security, a "secundus auctor".

The vulgar practice of granting a secundus auctor alongside a stipulation for eviction in the sale of res mancipi is moreover recorded in surviving contracts from the second century AD. For instance, at the emptio pueri Seleuciae pieriae contracta $^{117}(\mathrm{AD} 166)$ a seller gives a stipulation for eviction ("si quis eum puerum partemve eius evicerit, simplam pecuniam sine denuntiatione recte dare stipulatus est") which he reinforces with a guarantor who grants his auctoritas ("id fide sua et auctoritate esse iussit C. Iulius Antiochus"). ${ }^{118}$ The reference to the auctoritas of the guarantor may hint to the fact that the practice of granting a "secundus auctor" was borrowed from the mancipatio, ${ }^{119}$ which may be particularly the case in the document under analysis since, as noted by Koops, the presence of five witnesses

116 It is moreover worth noting that Varro De lingua Latina 6 74, should not be related with the satisdatio secundum mancipium and the limitations of guarantors at the mancipatio in general, as it has been often been claimed in the past (eg Lenel 1927: 548; Meylan 1948: 14; Arangio-Ruiz 1954: vol 2 331; Sargenti 1962: 159). The text has in fact a much more restricted scope, as shown by De Simone 2009: 198-210.

117 FIRA 1968: vol 3 425-427 (§ 132).

118 The same pattern (stipulation for eviction with an "auctor secundus" at the sale of a res mancipi) may be found in other stipulations for eviction dating from the classical period, such as FIRA 1968: vol 3432 (§ 134) (emptio puellae Ravennae facta, second century AD): “Aescina philium Flavianum secumdum auctorem exstitise" and FIRA 1968: vol 3288 (§ 89) (emptio ancillae,

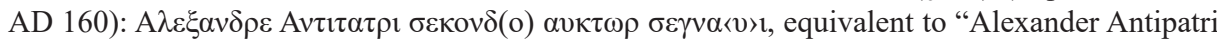
secundus auctor signavi". In several other texts, the stipulation for eviction is coupled with a personal security, but no reference is made to the guarantor's auctoritas or to the fact that he acts as an auctor secundus. Some documents written in Greek use the similar term $\beta \varepsilon \beta \alpha i \omega \sigma i s$,

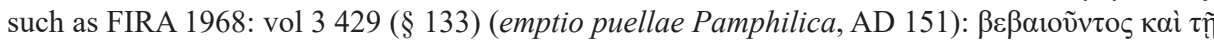

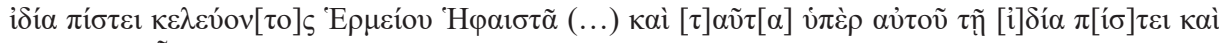

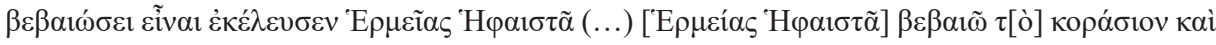

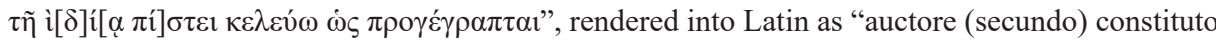
et fide sua (esse) iubente Hermia Hephaestae filio (...) haec autem pro fide sua et auctoritate esse iussit Hermias Hephaestae filius (...) Hermias Hephaestae filius puellae vendendae auctor sum et mea fide (esse) iubeo ita ut supra scriptum est". See, moreover, Straus 2004: 139-152 on the $\beta \varepsilon \beta \alpha i \omega \sigma ı \varsigma$ as surety for eviction in papyrological sources.

119 FIRA 1968: vol $3288(\S 89)$ reports in fact that the mancipatio was concluded. 
suggests that the parties tried to stick close enough to the forms of the mancipatio, despite the fact that they did not feel the need to include the clause "mancipioque accepit". ${ }^{120}$

Through this analysis, the obscure use of a "secundus auctor" at the sale of res mancipi can be explained as an (unnecessary) precaution which followed the model of the satisdatio secundum mancipium, just like the practice of granting a stipulation against eviction alongside a mancipatio. Both commercial usages further confirm that the repromissio and satisdatio secundum mancipium must have had a relevant position in everyday practice. Moreover, the widespread use of a "secundus auctor" may explain the term "stipulatio auctoritatis" of the Fragmenta Vaticana 10, which could be regarded as the stipulation granted by the guarantor of the sale, thus encompassing both the legally accurate usage of the satisdatio secundum mancipium when an agent mancipated and the vulgar practice of granting an auctor secundus whenever a res mancipi was sold.

\section{Historical development of the satisdatio and repromissio secundum mancipium}

The additional information given by D 212391 and by the documents of legal practice enables a reconstruction of the historical origins of the repromissio and satisdatio secundum mancipium. In the course of the third century BC, an increasing number of slaves and sons-in-power acted as commercial intermediaries. The basic rule of thumb was that the position of the paterfamilias could be improved by the acts of his slaves and sons-in-power, but that acts which were burdensome had to be authorised by him. ${ }^{121}$ It was in this context that the actiones adiecticiae came into scene, allowing those who contracted with a person alieni iuris to hold the paterfamilias liable.

Concerning the transfer of ownership by mancipatio or traditio, as shown above, an authorised non-owner - whether he was a person sui iuris or alieni iuris would validly alienate if he acted according to the owner's authorisation (voluntate domini). However, as it appears from D 21239 1, the mancipatio performed by an agent would not give rise to responsibility for auctoritas. The ground for this limitation is unknown, but one may suspect that, since the auctoritas was a form of statutory liability, it must have covered a specific range of situations which did not comprise alienations concluded by a non-owner acting on behalf of the owner. ${ }^{122}$

120 Koops 2014: 49-50.

121 D 35 38(39); D 5017 133. See, on this point, Miceli 2008: 38; Coppola Bisazza 2008: 101; Rodríguez Diez 2017: 73-75.

122 This idea was already proposed by Calonge 1968: 21 when discussing the letter of Cicero to Atticus: "En la situación que delata el texto ciceroniano parece lógico pensar que la presencia de satisdationes no tenga otro motivo que la ausencia del mancipio dans de Roma; quizá por ello no podría entrar en juego la general protección de la auctoritas que sería necesario suplir, al menos por lo que se refiere a la posibilidad de evicción, con garantes." 
The juristic solution to this limitation was that the agent should grant a special repromissio in order to allow the buyer to hold the dominus negotii liable with the corresponding action. If the agent was a person sui iuris, he would bind himself; if the agent was a person alieni iuris, the paterfamilias would be liable to the extent of the actiones adiecticiae. It is therefore no wonder that the first mentions of the repromissio and the actiones adiecticiae are to be found at around the same period, towards the second century BC. ${ }^{123}$

The repromissio secundum mancipium had some obvious disadvantages compared to the responsibility for auctoritas, especially because the dominus negotii had a reduced liability, and was only bound if the act of intermediation fell within the scope of one of the actiones adiecticiae (which was exceptional if the agent was a person sui iuris). Moreover, considering the perils threatening the buyer who acquired by mancipatio from an agent, the repromissio at some point had to be reinforced by adding an additional personal security, thus becoming a satisdatio secundum mancipium. The presence of guarantors would give the buyer a strong surety in order to claim the stipulated duplum in case of eviction, which is why the satisdatio must have been much more common in legal practice than the repromissio, as suggested by the formula Baetica. All of this supports the claim that it was included among the praetorian stipulations. Therefore, when Cicero writes to Atticus that some satisdationes had to be granted, it is probable that the buyer could compel Atticus and seek liability if the surety was not granted. Nonetheless, the repromissio did retain a certain role, as attested by the formula Baetica.

\section{Significance of the satisdatio and repromissio secundum mancipium}

According to this historical reconstruction, the satisdatio and repromissio secundum mancipium must have had an enormous importance in the development of the responsibility for eviction. It was in the context of the mancipatio by a non-owner that jurists for the first time had to address the problem of making someone liable for eviction outside the boundaries of the auctoritas. If this problem was not solved, no seller would have been willing to acquire by mancipatio from an agent. The repromissio and satisdatio enabled the buyer to seek responsibility from the dominus negotii through the corresponding action - de peculio, quod iussu, etc - and the responsibility of the seller himself in case he was a person sui iuris. When the jurists had to determine the content of these sureties, their immediate reference was the responsibility for auctoritas. While it is difficult to determine to what extent the liability for auctoritas influenced the content of the repromissio and satisdatio, it seems likely that the seller would stipulate for twice the price of the thing sold. ${ }^{124}$

123 Miceli 2008: 37, 38 n 15. For the dating of the actio de peculio, see Pesaresi 2012: 169-173.

124 Bechmann 1876: 370; Girard 1923: 62; Ankum 2013: 15. 
However, as shown by D 21239 1, the liability which rose from these sureties was not identical to that of the auctoritas.

The possibility of introducing the responsibility for eviction through a stipulation must have been an eye-opener to the jurists, who in the second century $\mathrm{BC}$ introduced the stipulatio habere licere for the sale of res nec mancipi, ${ }^{125}$ another case where - just as in the repromissio and satisdatio secundum mancipium the transfer of Quiritary ownership was not coupled with a form of liability for eviction. ${ }^{126}$ Moreover, as the buyer who acquired a res mancipi by traditio was increasingly protected by the praetor, the inconveniences of the lack of liability in case of eviction must have become more pressing. The satisdatio and repromissio secundum mancipium appeared as an immediate model to make the seller liable, which is why jurists conceived a stipulation for double which encompassed the sale of res mancipi delivered by traditio: the stipulatio duplae. ${ }^{127}$ The main differences were that the stipulatio duplae was not performed secundum mancipium and was not restricted to the alienations by agents. It is furthermore difficult, due to the scarcity of sources, to determine whether there were further differences between these institutions, although Ankum's analysis suggest that the liability which rose from the satisdatio and repromissio secundum mancipium might have been closer to that of the auctoritas than to the stipulatio duplae. ${ }^{128}$

It should be noted at this point that the development of these stipulations was intimately linked to the in rem protection that the buyer could obtain. ${ }^{129}$ The seller would only take upon himself the responsibility for eviction if the buyer could defend his position in terms of real rights. Therefore, the repromissio secundum mancipium could only have been granted already at the beginning of the second century BC - as attested by Plautus - if the buyer obtained Quiritary ownership over the res mancipi through mancipatio. The actio Publiciana and the exceptio rei venditae et traditae were certainly not available at such an early stage,,${ }^{130}$ which is why it would have been almost unimaginable that the seller would have been willing to guarantee the position of the buyer if the latter could not successfully defend himself. It therefore makes sense that the stipulatio duplae was introduced to protect the buyer of a res

125 Varro De re rustica 22 5-6; 23 5; 24 5. For recent surveys on this point, see Dalla Massara 2007: 286-293 and Guida 2013: 70-76.

126 Dalla Massara 2007: 288.

127 Varro De re rustica 210 5. See, on this point, Girard 1923: 101; Arangio-Ruiz 1954: vol 2 341; Guida 2013: 87-90

128 See Ankum 1981: 775-782 and Ankum 2013: 19-22, 27, although the differences that the author spots may go too far, since he assumes that the liability rising from the satisdatio and repromissio must have been identical to the obligation of auctoritas.

129 Cristaldi 2007: 10-13, 121ff; Guida 2013: 35-58.

130 While the exact date of introduction of these remedies is disputed, scholars agree that it could not have been earlier than the second half of the second century BC. For a status quaestionis of the traditional scholarship on this point, see Sansón Rodríguez 1998: 129-134, 155-157. 
mancipi who obtained it by traditio only after the praetor had created the actio Publiciana and the exceptio rei venditae et traditae.

According to this description, the satisdatio and repromissio secundum mancipium were not insignificant sureties in Roman law. The fact that the formula Baetica lists them among the sources of liability for the seller shows that they were widespread in commercial practice, coexisting alongside the general stipulations for eviction through the classical period. They were not used incidentally and merely as a reinforcement for the liability of the seller, as seems to have been the case regarding the cautio rem ratam haberi that could be granted when transferring ownership.

The only reason why there is so little evidence on the satisdatio and repromissio secundum mancipium is because these sureties were intimately linked to the mancipatio. Moreover, the idea that the buyer could compel the seller (mancipio dans) to conclude a satisdatio secundum mancipium - being a stipulatio praetoria was in contradiction with the general rules regarding the law of sale as indicated in the previous paragraph, which may moreover explain why such few texts on these sureties were preserved in the Digest.

Curiously enough, the downfall of the mancipatio seems to be in direct connection with the introduction of the satisdatio and repromissio secundum mancipium. Originally, the buyer had relevant incentives to require that the seller performed the mancipatio, not only because he would become Quiritary owner, but also because he would eventually be able to hold him liable through the actio auctoritatis. Afterwards, the satisdatio and repromissio secundum mancipium introduced the possibility to hold the seller liable when the mancipatio was performed by an agent. This in turn opened the possibility for granting other stipulations for eviction even when the thing was not mancipated, especially considering that the buyer would obtain the habere licere, which was secured by the praetorian remedies in case the delivered object was a res mancipi. At some point it must have appeared evident that the mancipatio had become nothing but a tiresome formality, with almost no practical advantage over a traditio secured by a stipulatio duplae. The mancipatio was thus gradually set aside, carrying the satisdatio and repromissio secundum mancipium along with it.

\section{Conclusion}

The most likely role of the satisdatio and repromissio secundum mancipium, according to the few available sources, was to serve as a surety for eviction, particularly when an agent transferred ownership. The main difficulty is to determine whether these sureties were granted in the context of a traditio or a mancipatio, as well as the exact reason for granting them. Regarding the first issue, it has been argued that the satisdatio and repromissio could not have been granted in the context of a traditio, since their scope of application would overlap with the stipulatio duplae, as well as with the exceptio rei venditae et traditae. On the other hand, while scholars 
traditionally have assumed that a mancipatio could not be concluded by an agent, this assumption is not based on the sources, but rather on preconceptions which one may nowadays label as obsolete. Since there is no overlap with other institutions in the context of the mancipatio, the satisdatio and repromissio secundum mancipium are more likely to have been granted when an agent mancipated.

The role of the satisdatio and repromissio, as shown by D 212391 , was to provide a form of liability for eviction, since the responsibility for auctoritas would not rise when the mancipatio was concluded by an agent. The satisdatio and repromissio secundum mancipium were the juristic solution to the limited scope of the liability for auctoritas, thus inaugurating the trend of granting stipulations for eviction. These sureties retained a relevant role in the classical period, leaving moreover traces in legal practice, such as the possibility to stipulate for eviction when mancipating or the usage of offering guarantors when granting a stipulatio duplae.

The reconstruction that has been offered above not only seeks to make the most out of the few sources on the subject, but also to harmonise these sureties with other institutions that protected the buyer from the perspective of personal (stipulatio duplae) and real rights (exceptio rei venditae et traditae). This attempt allows one to understand the coexistence of the satisdatio and repromissio alongside other stipulations for eviction, as well as its scarce mentions within the sources. This historical framing shows that these sureties were of key importance in the evolution of the responsibility for eviction in Roman law.

\section{Bibliography}

Amirante, L (1951) "[Review] Meylan Ph, La 'satisdatio secundum mancipium' in Revue historique de droit français et étranger 426 (1948) 3 ss" IVRA Rivista internazionale di diritto romano e antico 2: 340-344

Ankum, JA (1978) "Mancipatio by slaves in classical Roman law?" in W de Vos, W Dean \& I Leeman (eds) Essays in Honour of Ben Beinart vol 1 (Cape Town, Wetton, Johannesburg): $1-18$

Ankum, JA (1979) 'L'actio auctoritatis appartenant à l'acheteur mancipio accipiens a-t-elle existé?" Atti dell'Accademia Romanistica Costantiniana 3: 1-45

Ankum, JA (1981) "Alla ricerca della repromissio e della satisdatio secundum mancipium" Atti dell'Accademia Romanistica Costantiniana 4: 741-792

Ankum, JA (1984) "Mancipatio by slaves in classical Roman law" in J van der Westhuizen (ed) Huldigingsbundel Paul van Warmelo (Pretoria): 5-17

Ankum, JA (2002) "La responsabilité du vendeur pour eviction dans le cas de sous-aliénation en droit romain classique" in L de Ligt et al (eds) Viva Vox Iuris Romani, Essays in Honour of Johannes Emil Spruit (Amsterdam): 229-242

Ankum, JA (2013) "Noch einmal: die repromissio und die satisdatio secundum mancipium im klassischen römischen Recht” in M Armgardt, F Klinck \& I Reichard (eds) Liber amicorum Christoph Krampe zum 70. Geburtstag (Berlin): 13-28 


\section{JAVIER E RODRÍGUEZ DIEZ}

Ankum, JA (2014) "Problems concerning laudatio auctoris and denuntiatio litis made by the buyer in classical Roman law" in R van den Bergh et al (eds) Meditationes de Iure et Historia, Essays in Honour of Laurens Winkel, Fundamina (Editio Specialis): 1-14

Arangio-Ruiz, V (1954) La compravendita in diritto romano vols 1 \& 2 (Naples)

Bechmann, A (1876) Der Kauf nach gemeinem Recht, Erster Theil: Geschichte des Kaufs im römischen Recht (Erlangen)

Brägger, R (2012) Actio auctoritatis (Berlin)

Calonge, A (1968) Evicción, Historia del concepto y análisis de su contenido en el Derecho romano clásico (Salamanca)

Camodeca, G (1987) 'Le 'emptiones' con 'stipulatio duplae' dell'Archivio Puteolano dei Sulpici (TP 98; 57; 103)” Labeo 33: 167-185

Camodeca, G (2007) “Ancora sui documenti di emptio-venditio: riedizione della tabula cerata londinense della puella Fortunata" in FM d'Ippolito (ed) $\varphi_{\text {i }} i \alpha$, Scritti per Gennaro Franciosi vol 1 (Naples): 397-404

Camodeca, G (2017) Tabulae Herculanenses, Edizione e commento vol 1 (Rome)

Coppola Bisazza, G (2008) Dallo iussum domini alla contemplatio domini, Contributo allo studio della storia della Rappresentanza (Milan)

Corbino, A (1976) "La legittimazione a 'mancipare' per incarico del proprietario" IVRA Rivista internazionale di diritto romano e antico 27: 50-71

Corbino, A (1984) "Forma librale ed intermediazione negoziale" in Sodalitas. Scritti in onore di Antonio Guarino vol 5 (Naples): 2257-2272

Cristaldi, SA (2007) Il contenuto dell'obbligazione del venditore nel pensiero dei giuristi dell'età imperiale (Milan)

Cristaldi, SA (2011) "Diritto e pratica della compravendita nel tempo di Plauto" in Index, Quaderni camerti di studi romanistici 39: 491-523

Dalla Massara, T (2007) "Garanzia per evizione e interdipendenza delle obbligazioni nella compravendita romana" in L Garofalo (ed) La compravendita e l'interdipendenza delle obbligazioni nel diritto romano vol 2 (Padua): 277-310

Daube, D (1960) "Utiliter agere" in IVRA Rivista internazionale di diritto romano e antico 11: 69-148

De Simone, M (2009) "Vas appellatus qui pro altero vadimonium promittebat'. Per una lettura di Varro, De ling lat, 6,74" Annali del Seminario Giuridico della Università di Palermo 53: $163-222$

Ernst, W (1995) Rechtsmängelhaftung (Tübingen)

Finkenauer, T (2010) Vererblichkeit und Drittwirkungen der Stipulation im klassischen römischen Recht (Tübingen)

Girard, PF (1923) Mélanges de Droit Romain, vol 2: Droit privé et procédure (Paris)

Guida, G (2013) La tutela del compratore in caso di evizione fra garanzia e responsabilità (Naples)

Kaser, M (1970) "Die römische Eviktionshaftung nach Weiterverkauf” in WG Becker \& L Schnorr von Carolsfeld (eds) Sein und Werden im Recht. Festgabe für Ulrich von Lübtow (Berlin): 481-492 


\section{MANCIPATIO BY AN AGENT AND THE SATISDATIO}

Keil, H \& Mommsen, Th (1864) Grammatici Latini, vol IV: Probi, Donati, Servii qui feruntur de arte grammatica libri, et Notarum Laterculi (Leipzig)

Koops, E (2014) “Tekst \& Uitleg $A E$ 1896, $21=F I R A^{2} 132=$ P. Lond. I 229” Groninger opmerkingen en mededelingen 31: 47-54

Lenel, O (1889) Palingenesia iuris civilis vols 1 \& 2 (Leipzig)

Lenel, O (1927) Das Edictum Perpetuum, Ein Versuch zu seiner Wiederherstellung (Leipzig)

Mattiangeli, D (2011) “La 'mancipatio emptionis causa' delle tabolette transilvaniche" Seminarios Complutenses de Derecho Romano 23-24: 307-323

Meylan, Ph (1948) "La 'satisdatio secundum mancipium"' Revue historique de droit français et étranger 25 (1948): 1-35

Miceli, M (2008) Studi sulla 'rappresentanza' nel diritto romano (Milan)

Mitteis, L (1908) Römisches Privatrecht bis auf die Zeit Diokletians (Leipzig)

Mostert, DF (1969) “Uitwinning by die Koopkontrak in die Romeinse Reg” Acta Juridica: 1-121

Pesaresi, R (2012) Studi sull'actio de peculio (Bari)

Reduzzi Merola, F (2004) "Ancora su D 21,2,39,1, stipulatio duplae e traditio" in M GarridoHory \& A Gonzales (eds) Histoire, Espaces et Marges de l'Antiquité, Hommages à Monique Clavel Lévêque vol 3 (Besançon): 316-321

Rodríguez Diez, JE (2016) Potestas alienandi, Transfer of Ownership by a Non-owner from Roman Law to the DCFR (Oisterwijk)

Rodríguez Diez, JE (2017) "Primitive prohibition of direct representation in Roman law scholarship: Origins, sources and flaws" Fundamina 23(2): 62-80

Sansón Rodríguez, MV (1998) La transmisión de la propiedad (Barcelona, Madrid)

Sargenti, M (1962) “La 'satisdatio secundum mancipium' e la 'stipulatio habere licere' nel quadro della garanzia per evizione nella compravendita romana" Bullettino dell'Istituto di Diritto Romano "Vittorio Scialoja" 65: 151-171

Straus, JA (2004) L'achat et la vente des esclaves dans l'Egypte romaine (Munich, Leipzig) 